\title{
Immunological Adjuvants and Vaccines
}




\section{NATO ASI Series}

\section{Advanced Science Institutes Series}

A series presenting the results of activities sponsored by the NATO Science Committee, which aims at the dissemination of advanced scientific and technological knowledge, with a view to strengthening links between scientific communities.

The series is published by an international board of publishers in conjunction with the NATO Scientific Affairs Division
A Life Sciences
B Physics
C Mathematical and Physical Sciences
D Behavioral and Social Sciences
E Applied Sclences
F Computer and Systems Sciences
G Ecological Sciences
H Cell Biology

\author{
Plenum Publishing Corporation \\ New York and London \\ Kluwer Academic Publishers \\ Dordrecht, Boston, and London \\ Springer-Verlag \\ Berlin, Heidelberg, New York, London, \\ Paris, and Tokyo
}

Recent Volumes in this Series

Volume 174-Cell and Molecular Biology of Artemia Development edited by Alden H. Warner, Thomas H. MacRae, and Joseph C. Bagshaw

Volume 175-Vascular Endothelium: Receptors and Transduction Mechanisms edited by John D. Catravas, C. Norman Gillis, and Una S. Ryan

Volume 176-Processing of Sensory Information in the Superficial Dorsal Horn of the Spinal Cord edited by F. Cervero, G. J. Bennett, and P. M. Headley

Volume 177-Prostanoids and Drugs edited by B. Samuelsson, F. Berti, G. C. Folco, and G. P. Velo

Volume 178-The Enzyme Catalysis Process: Energetics, Mechanism, and Dynamics edited by Alan Cooper, Julien L. Houben, and Lisa C. Chien

Volume 179-Immunological Adjuvants and Vaccines edited by Gregory Gregoriadis, Anthony C. Allison, and George Poste

Volume 180-European Neogene Mammal Chronology edited by Everett $\mathrm{H}$. Lindsay, Volker Fahlbusch, and Pierre Mein

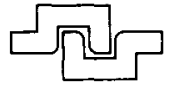

Series A: Life Sciences 


\section{Immunological Adjuvants and Vaccines}

Edited by

Gregory Gregoriadis

Royal Free Hospital School of Medicine London, United Kingdom

\section{Anthony C. Allison}

Syntex Research

Palo Alto, California

and

George Poste

Smith Kline French Laboratories

Philadelphia, Pennsylvania

Plenum Press

New York and London

Published in cooperation with NATO Scientific Affairs Division 
Proceedings of a NATO Advanced Study Institute on Immunological Adjuvants and Vaccines, held June 24-July 5, 1988, in Cape Sounion Beach, Greece

NATO Advanced Study Institute on Immunological Adjuvants and Vaccines (1988: Ájra Sounion, Greece)

Immunological adjuvants and vaccines / edited by Gregory Gregoriadis, Anthony C. Allison, and George Poste.

p. $\quad \mathrm{cm}$. - (NATO ASI series. Series A, Life sciences; v. 179)

"Proceedings of a NATO Advanced Study Institute on Immunological Adjuvants and Vaccines, held June 24-July 5, 1988, in Capa Sounion Beach, Greece"-T.p. verso.

"Published in cooperation with NATO Scientific Affairs Division."

Includes bibliographical references.

ISBN 978-1-4757-0285-9 ISBN 978-1-4757-0283-5 (eBook)

DOI 10.1007/978-1-4757-0283-5

1. Immunological adjuvants-Congresses. 2. Vaccines-Congresses. I. Gregoriadis, Gregory. II. Allison, Anthony C. (Anthony Clifford), 1925- III. Poste, George. IV. North Atlantic Treaty Organization. Scientific Affairs Division. V. Title. VI. Series.

[DNLM: 1. Adjuvants, Immunologic-congresses. 2. Vaccines-congresses. QW 800 N279i 1988]

QR187.3.N37 1988

$615^{\prime} .372-\mathrm{dc} 20$

DNLMÇDLC

for Library of Congress

89-25561

(C) 1989 Plenum Press, New York

Softcover reprint of the hardcover 1st edition 1989

A Division of Plenum Publishing Corporation

233 Spring Street, New York, N.Y. 10013

\section{All rights reserved}

No part of this book may be reproduced, stored in a retrieval system, or transmitted in any form or by any means, electronic, mechanical, photocopying, microfilming, recording, or otherwise, without written permission from the Publisher 


\section{PREFACE}

Vaccination, chiefly responsible for the eradication of smallpox and the control of poliomyelitis and German measles in man and of foot-andmouth, Marek's and Newcastle disease in domestic animals, remains the best answer to infectious diseases. Early vaccines were live wild type organisms but these have been largely replaced by attenuated or killed organisms or by purified components (subunits) thereof. More recently, developments in recombinant DNA techniques, the advent of monoclonal antibodies and progress in our understanding of the immunological structure of proteins, have laid the foundations for a new generation of vaccines. For instance, subunit vaccines have been produced through gene cloning and a number of peptides mimicking small regions of proteins on the outer coat of viruses and capable of eliciting virus neutralizing antibodies, have been synthesized. Such vaccines are defined at the molecular level, can elicit immune responses controlling specific infectious organisms and are, thus, potentially free of the problems inherent in conventional ones. However, because subunit and peptide vaccines are only weakly or non-immunogenic, they require the presence of immunological adjuvants. These are a diverse array of agents that promote specific humoural and/or cell-mediated immunity responses to antigens.

This book contains the proceedings of the 1st NATO Advanced Studies Institute "Immunological Adjuvants and Vaccines" held in Cape Sounion Beach, Greece during 24 June-5 July, 1988. It deals with traditional and modern immunological adjuvants as applied to a variety of conventional and new generation vaccines, mechanisms of adjuvanticity and related immune responses as well as optimization of such responses by the use of appropriate adjuvant formulations. We express appreciation to Professors Ruth Arnon and J.H.L. Playfair for their advice in the planning of the ASI, to Dr. G. Deliconstantinos who, as Chairman of the local committee, contributed most effectively to its success, and to Mrs. A. Massaro for her help with practical aspects of the ASI. We are particularly grateful to Mrs. Susan Gregoriadis for her invaluable input in the editing of the book. The ASI was held under the sponsorship of NATO Scientific Affairs Division and cosponsored and generously financed by Smith Kline and French Laboratories (Philadelphia). Financial assistance was also provided by Syntex (Palo Alto), Biophor (College Station), Sclavo (Sienna), Institut Merieux (Lyons), Hoffmann-La-Roche (Basle), Boehringer (Mannhein), Merck Sharp and Dohme (West Point), Organon (Oss), Connaught Laboratories (Willowdale), Schering (W. Berlin), Ciba Geigy (Horsham), Merz and Dade (Dudingen), Johnson and Johnson (La Jolla) and Northumbria Biologicals (Cramlington). 
CONTENTS

Antigens and Adjuvants for a New Generation of Vaccines

A.C. Allison

Structural and Functional Studies on MHC-Peptide Antigen Interactions

H.M. Grey, S. Buus and A. Sette

Role of Interferon Gamma in the Priming of Human Accessory Cells for Autocrine Secretion of Monokines (IL-1 and TNF) and HLA Class II Gene Expression

J.L. Virelizier, F. Arenzana-Seisdedos and S.C. Mogensen

Chemical Events in Immune Induction: Evidence for a Covalent Intercellular Reaction Essential in Antigen-specific $\mathrm{T}$-cell Activation

J. Rhodes

Aluminium Salts: Perspectives in their Use as Adjuvants

R. Bomford

Saponins as Immunoadjuvants

R. Bomford

The Immunoadjuvant Dimethyldioctadecylammonium Bromide

H. Snippe and C.A. Kraaijeveld

Bacterial Endotoxins: Relationships between Chemical Structure and Biological Activity

61

E.T. Rietschel, L. Brade, U. Schade, U. Seydel,

U. Zahringer, H. Loppnow, H-D. Flad and H. Brade

Recombinant Ganma Interferon as an Immunological Adjuvant

J.H.L. Playfair, A.W. Heath and J.B. De Souza

The Immunoadjuvant Action of Liposomes: Role of Structural Characteristics

G. Gregoriadis, L. Tan and Q. Xiao

Immunoadjuvant Action of Liposomes: Mechanisms

N. van Rooijen and D. Su

Liposomal Vaccine to Streptococcus Pneumoniae Type 3 and 14

H. Snippe, A.F.M. Verheul and J.E.G. van Dam 
Liposomes as Carriers of Vaccines: Development of a

Liposomal Malaria Vaccine

C.R. Alving, R.L. Richards, M.D. Hayre, W.T. Hockmeyer and R.A. Wirtz

Nonionic Block Copolymer Surfactants as Immunological

Adjuvants: Mechanisms of Action and Novel Formulations

R.L. Hunter, B. Bennett, D. Howerton, S. Buynitzky and

I.J. Check

Use of Syntex Adjuvant Formulation to Augment Humoral

Responses to Hepatitis B Virus Surface Antigen and

to Influenza Virus Hemagglutinin

N.E. Byars, G. Nakano, M. Welch and A.C. Allison

Immunostimulating Complex (Iscom)

B. Morein, K. Lovgren and S. Hoglund

Recombinant Sub-unit and Peptide Viral Vaccines

F. Brown

Synthetic Antigens and Vaccines

R. Arnon

The Development and Preliminary Clinical Evaluation of an Antifertility Vaccine

P.D. Griffin

Recent Progress with Vaccines against Epstein-Barr Virus Infection

M.A. Epstein

Measurement of Antibody Affinity, Concentration and Isotype to Evaluate Antigens, Adjuvants, and Immunization Regimens in Vaccine Research

B.W. Hughes, J.S. Kenney and A.C. Allison

Recommendations for the Assessment of Adjuvants

(Immunopotentiators)

D.E.S. Stewart-Tull

Interaction between Industry and the Basic Researcher in the University during Vaccine Development

D.E.S. Stewart-Tull

Contributors

Index 